DOI: $10.7242 / 2658-705 \mathrm{X} / 2019.3 .6$

УДК 579.66:661.8

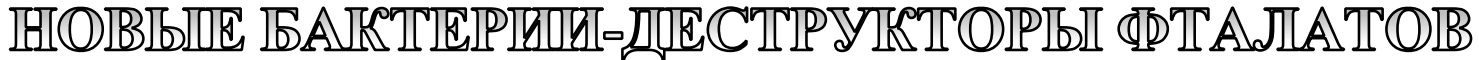 IBIЗ PA

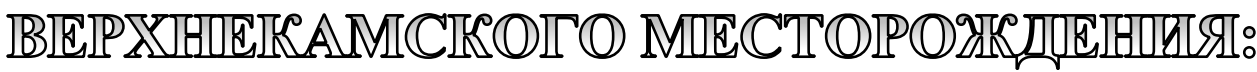

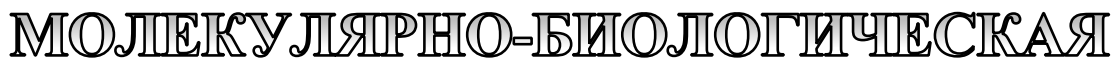

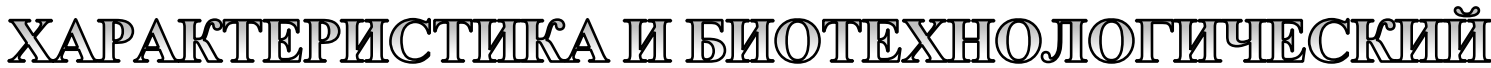

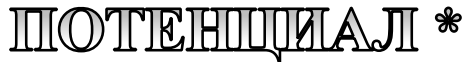

Е.Г. Плотникова, Институт экологии и генетики микроорганизмов УрО РАН

О.В. Ястребова, Институт экологии и генетики микроорганизмов УрО РАН

Е.С. Корсакова, Институт экологии и генетики микроорганизмов УрО РАН

А.А. Пьянкова, Институт экологии и генетики микроорганизмов УрО РАН

А.О. Воронина, Институт экологии и генетики микроорганизмов УрО РАН

Исследование направлено на решение актуальной проблемы очистки объектов окружающей среды от стойких органических загрязнителей, одной из самых представительных групп которых являются фрталаты. При проведении исследовательских работ осуществлен отбор и химический анализ 12 образцов загрязненных/засоленных почв и отходов калийного производства (г. Березники, Пермский край). Из полученных на их основе накопительных культур (НК) выделено 55 штаммов бактерий-деструкторов орто-ФК, которые были идентифицированы (на основании анализа фрагмента гена 16S pPHK) как представители родов Arthrobacter, Bacillus, Erythrobacter, Rhodococcus, Idiomarina, Oceanisphaera, Martelella, Marinobacter, Alcanivorax, Stappia.

Из рабочей коллекции микроорганизмов Лаборатории молекулярной микробиологии и биотехнологии «ИЭГМ УрО РАН» для исследований было отобрано 20 штаммов-деструкторов орто-ФК. Установлено, что штаммыдеструкторы орто-ФК способны утилизировать моно- и полиароматические углеводороды (нафталин, фенантрен, салицилат, бензоат, гентизат), а также расти на средах с повышенной концентрацией хлорида натрия (до 100 г/л). Восемь штаммов, представителей родов Halomonas, Pseudomonas, Oceanisphaera, Dietzia, Martelella и Rhodococcus, способны использовать эфиры фрталевой кислоты - дибутилфталат (ДБФ) и диэтилфталат (ДЭФ) в качестве единственного источника углерода и энергии. Штаммы утилизировали 90-98\% ДБФ и 49-80\% ДЭФ (концентрация фталатов 500 мг/л) без соли в среде культивирования, а также в присутствии 50 г/л $\mathrm{NaCl}$. Таким образом, в результате проведенных исследований выявлены активные штаммы-деструкторы фрталатов, адаптированные к росту в условиях

* Исследование выполнено при финансовой поддержке гранта РФФИ и Министерства образования и науки Пермского края в рамках научного проекта № 16-44-590968 p_a «Новые бактерии-деструкторы фталатов из района солеразработок Верхнекамского месторождения: молекулярно-биологическая характеристика и биотехнологический потенциал». 
повышенного засоления среды, перспективные для разработки методов биоремедиации техногеннозагрязненных почв.

Ключевые слова: аэробные бактерии, орто-фталиевая кислота, дибутилфталат, диэтилфталат, деструкиия, хлорид натрия.

\section{Введение}

В настоящее время все более актуальной становится проблема антропогенного загрязнения окружающей среды устойчивыми токсичными соединениями, имеющими тенденцию к накоплению в экосистемах и представляющими опасность для здоровья человека и животных. К таким соединениям, наиболее интенсивно поступающим в окружающую среду с промышленными выбросами и бытовыми отходами, в последние десятилетия относят фталаты.

Фталаты имеют широкое применение в качестве пластификаторов, приблизительно 87\% всех этих сложных соединений используется для пластификации поливинилхлорида (ПВХ), при синтезе полиэфирных волокон и полиэтилена. Наиболее широкое применение в химической промышленности имеют такие производные фталевой кислоты, как диметилфталат (ДМФ) и дибутилфталат (ДБФ). Обладая высокой растворяющей способностью и низкой вязкостью, они используются для изменения свойств полимеров с целью повышения их эластичности и морозостойкости, в частности при производстве небьющегося стекла, искусственных пленок и кож, кабельных пластикатов.

Молекулы фталатов химически не связаны с полимерными цепями ПВХ и поэтому легко выделяются в окружающую среду, попадая в организм человека через пищу, кожу или при вдыхании $[1,10]$. Фталаты и их метаболиты обладают гепатотоксичными, тератогенными и канцерогенными свойствами, способны накапливаться в организме и признаны опасными для человека и животных $[10,17]$. Удаление из окружающей среды данных соединений может осуществляться как с помощью химических, физических (гидролиз, фотолиз и т.п.), так и биологических мето- дов (микробная деструкция) [10]. Среди штаммов, осуществляющих аэробную деструкцию фталатов, обнаружены бактерии различных филумов, наиболее часто встречаются представители родов Arthrobacter, Rhodococcus, Bacillus, Pseudomonas, Burkholderia, Sphingomonas $[6,10,14]$. Метаболические пути разложения сложных эфиров фталевой кислоты аэробными бактериями сочетают два процесса - первичную деградацию диэфиров фталата до моноэфиров и последующую их деструкцию до орто-ФК, являющейся центральным метаболитом деструкции большинства фталевых эфиров. Дальнейшее разложение орто-ФК осуществляется через образование протокатеховой кислоты (ПКК), в качестве ключевого метаболита, до основных продуктов жизнедеятельности микробной клетки [17].

Установлено, что значительную роль в бактериальной деградации фталатов играют условия культивирования. Отклонение параметров культивирования, таких как $\mathrm{pH}$, температура, минерализация среды, как в большую, так и в меньшую сторону, приводит к ухудшению деструкционных и ростовых характеристик штаммов $[8,10]$. Влияние уровня минерализации среды на эффективность биодеструкции фталатов изучено недостаточно. Встречаются лишь единичные сведения о штаммах микроорганизмов, выделенных из морской воды и способных разлагать фталаты в условиях осмотического стресса $[5,7,8]$.

Цель исследований - поиск и характеристика бактерий-деструкторов производных фталевой кислоты (фталатов), изолированных из засоленных/загрязненных почв и отходов производства калийных солей (Верхнекамское месторождение солей, Пермский край), оценка молекулярно-биологического, генетического потенциала выделенных штаммов-дест- 
рукторов с целью их дальнейшего использования в экобиотехнологии.

\section{Методы исследования}

Образцы галитовых отходов, грунта около солеотвалов, воды и донных отложений рассолосборника, а также ризосферы доминирующих растений, произрастающих в непосредственной близости от солеотвалов, отобраны на территории промышленных разработок Верхнекамского месторождения калийно-магниевых солей (предприятия ПАО «Уралкалий», г. Березники, Пермский край). Для оценки общего содержания водорастворимых солей в почвенном субстрате и шламах выявляли плотный остаток водной вытяжки общепринятыми методами [3]. Определение содержания катионов $\mathrm{Na}^{+}, \mathrm{K}^{+}$, $\mathrm{Ca}^{2+}$ и $\mathrm{Mg}^{2+}$ осуществляли на атомно-абсорбционном спектрофотометре АА-6300 («Shimadzu», Япония). Органические загрязнители определяли в хлороформенных экстрактах проб (образцов) с использованием хромато-масс-спектрометра Agilent 6890/5973N («Agilent», США). Для дальнейших исследований были отобраны высокоминерализованные образцы, в которых аналитическими методами обнаружены производные орто-фталевой кислоты (фталаты).

Выделение ДНК из отобранных образцов проводили с помощью набора Fast DNA Spin Kit («MP Biomedicals», США) согласно инструкции производителя. Для оценки качества экстрагированной ДНК измеряли концентрации с помощью прибора Qubit ${ }^{\circledR}$ Fluorometer и набора реактивов Quant-iT ${ }^{\mathrm{TM}}$ dsDNA BR Assay Kit («Invitrogen», США).

Бактерии выделяли методом накопительного культивирования с последующим высевом на селективные среды. Накопительные культуры получены путем инкубирования образцов (1 г) в минеральной среде Раймонда (МСР, 100 мл) [4], содержащей орто-ФК (1 г/л) качестве субстрата, в присутствии 30 г/л NaCl. Скрининг штаммов бактерий-деструкторов из рабочей коллекции микроорганизмов Лаборатории молекулярной микробиологии и биотехнологии «ИЭГМ УрО РАН», выделенных из района солеразработок, на способность к эффективной утилизации фталатов (ортоФК, ДБФ) проводили при повышенном содержании хлорида натрия в среде культивирования. Оценка способности бактерий-деструкторов разлагать фталаты проводилась при выращивании культур в жидкой МСР с орто-ФК (1 г/л) или ДБФ (1 г/л) в качестве субстрата с добавлением $\mathrm{NaCl}$ в концентрации 30-100 г/л.

Идентификацию выделенных и отобранных из рабочей коллекции активных штаммов-деструкторов проводили на основе морфологического описания колоний и клеток бактерий, а также анализа нуклеотидных последовательностей гена $16 \mathrm{~S}$ рРНК. Амплификацию фрагмента гена $16 \mathrm{~S}$ рРНК осуществляли с использованием бактериальных праймеров 27F и 1492R на амплификаторе «My Cycler» («Bio-Rad Laboratories», США) как описано [9]. $\begin{array}{cr}\text { Для амплификации } & p h t \text {-генов } \\ \text { использовали пhtBF }\end{array}$ (5'-GGAGCAGGTTCGGGTATCGG-3') и phtBR (5'-ACTTCGACGCCACATACA G-3'), сконструированные к консервативным участкам гена, кодирующего фталат 3,4-дегидрогеназу [15]. Электрофорез амплифицированных фрагментов ДНК для обнаружения ПЦР-продуктов проводили в горизонтальном агарозном геле $(0,8 \%)$ в буфере ТВЕ х 0,5 .

Структуру микробных сообществ исследовали методом денатурирующего градиентного гель-электрофореза (ДГГЭ) фрагментов гена $16 \mathrm{~S}$ рРНК, составляющих приблизительно 500 п.н., амплифицированных с использованием эубактериальных праймеров 27F (5 -AGAGTTTGATC(A/C)T GGCTCAG-3') и 518R (5'-ATTACCG CGGCTGCTGG-3') [16]. Праймер 27F включал на 5'-конце 40 п.н. GC-хвост (5'-CGCCCGCCGCGCCCCGCGCCCGTCC CG CCGCCCCCGCCCG-3'). Амплификацию и электрофорез осуществляли на амплификаторе «My Cycler» и приборе Dcode $^{\mathrm{TM}}$ Universal Mutation System («Bio- 
Rad Laboratories», США), соответственно, согласно протоколу [12]. ДНК была визуализирована после окрашивания бромистым этидием (0,5 мкг/мл) UV-трансиллюминацией и документирована системой Gel Doc XR («Bio-Rad Laboratories», США). Элюирование ДНК из геля осуществляли в стерильной деионизированной воде в течение 24 ч при температуре $4^{\circ} \mathrm{C}$. Элюированную ДНК использовали в качестве матрицы для ПЦР-реамплификации гена 16S рРНК при использовании бактериальных праймеров 27F и 1492R.

Определение нуклеотидных последовательностей осуществляли с применением набора реактивов Big Dye Terminator Cycle Sequencing Kit на автоматическом секвенаторе Genetic Analyser 3500XL («Applied Biosystems», США), приборная база кафедры ботаники и генетики растений Пермского национального исследовательского университета.

Оценка разложения ДБФ и ДЭФ бактериями проводилась методом ГЖХ-МС, как описано в [18]. Штаммы выращивались в жидкой МСР (в отсутствии или при содержании 30-90 г/л $\mathrm{NaCl}$ ) с субстратом - ДБФ или ДЭФ (500 мг/л). Клетки были собраны центрифугированием (9000 об/мин, 5 мин), дважды отмыты в МСР и инокулированы в 2 мл среды с ДБФ или ДЭФ (500 мг/л), не содержащей хлорид натрия, а также в присутствии соли (30-90 г/л). После инкубации в течение трех суток проводилась экстракция фталатов равным объемом гексана в течение 120 мин на шейкере при 100 об/мин. Анализ проводился на газовом хроматографе-масс-спектрометре «Agilent GC 7890A MS 5975C Inert XL EI/CI» (СШA).

Все эксперименты были выполнены в трехкратных повторностях. Полученные данные обрабатывали с использованием программы Microsoft Excel 2007.

\section{Результаты и их обсуждение}

На территориях предприятий БКПРУ1 и БКПРУ-3 ПАО «Уралкалий» (г. Березники, Пермский край), в весенне-летний период 2015, 2016 гг. были отобраны двенадцать образцов шламов, почв и ризосферы доминирующих растений вблизи солеотвалов, а также донных отложений сточного канала предприятия ООО «Промканал» (г. Березники), рассолосборника у солеотвала БКПРУ-3 и реки Зырянки, протекающей в непосредственной близости от калийного предприятия БКПРУ-1. Химический анализ отобранных проб почв/грунтов, шламов и донных отложений показал высокую степень их засоленности $(0,2-12,1 \%)$, а также значительное содержание органических загрязнителей (алканов, полициклических углеводородов, моноароматических углеводородов, эфиров фталевой кислоты).

Для изучения микробных сообществ исследуемых образцов молекулярно-генетическими методами из десяти образцов была выделена тотальная ДНК, концентрация которой составляла от 3,3 до 45,8 мкг/мл. Качество препаратов ДНК проверялось путем амплификации гена $16 \mathrm{~S}$ рРНК, в результате чего со всех препаратов ДНК были получены ампликоны. С использованием ПЦР в семи препаратах ДНК выявлены ключевые гены деструкции фталатов (орто-фталата). При электрофоретической разгонке в агарозном геле были обнаружены ампликоны размером 445 п.н., соответствующие по длине фрагменту гена $p h t B$, кодирующего фталат 3,4-дегидрогеназу, под действием которой иясс-3,4-дигидро-3,4-дигидроксифталат трансформируется до 3,4-дигидроксифталата.

Полученные данные указывают на присутствие в данных образцах аэробных грамположительных бактерий, осуществляющих деструкцию орто-ФК и ее производных через образование 3,4-дигидроксифталата. На основании полученных данных ПЦР-анализа гена $p h t B$ было отобрано 7 образцов, которые также характеризовались высоким содержанием водорастворимых солей $\left(\mathrm{Na}^{+}, \mathrm{K}^{+}, \mathrm{Ca}^{2+}, \mathrm{Mg}^{2+}\right)$ и органических загрязнителей, в частности фталатов.

С использованием отобранных образцов были получены накопительные культуры (НК), селектирующими 
факторами являлись орто-фталиевая кислота (орто-ФК, 1 г/л) и повышенное засоление среды (30 г/л $\mathrm{NaCl})$.

Методом ДГГЭ ПЦР-продуктов гена $16 \mathrm{~S}$ рРНК проведен сравнительный анализ бактериальных сообществ шлама, отобранного с поверхности шламохранилища предприятия БКПРУ-3 (образец 1), и грунта, отобранного вблизи солеотвала предприятия БКПРУ-3 (образец 2), а также полученных на их основе НК. Как показал ДГГЭ-анализ, сообщества обоих исследуемых образцов характеризовались отсутствием выраженных доминантных групп и более высоким таксономическим разнообразием, чем сообщества полученных на их основе НК (рисунок).

Фрагменты гена $16 \mathrm{~S}$ рДНК, отличающиеся электрофоретической подвижностью при разгонке ДГГЭ, были элюированы из геля и реамплифицированы. У семи фрагментов 16S рДНК определены нуклеотидные последовательности. Так, секвенирование фрагментов $16 \mathrm{~S}$ рДНК показало, что в обеих НК доминировали бактерии рода Halomonas, близкородственные штамму Halomonas ventosae Al12T. Уровень сходства по гену $16 \mathrm{~S}$ рРНК составлял 99\% с геном $16 \mathrm{~S}$ рРНК данного штамма в случае НК2 (ДГГЭ-полоса №3) и 89\% - для НК1 (ДГГЭ-полоса №6) (рис., табл. 1).

Таким образом, показано, что в микробных сообществах (MC) района солеразработок (калийное предприятие БКПРУ-3), а именно в МС шламохранилища (образец 1) и в МС грунта около солеотвала (образец 2), присутствуют

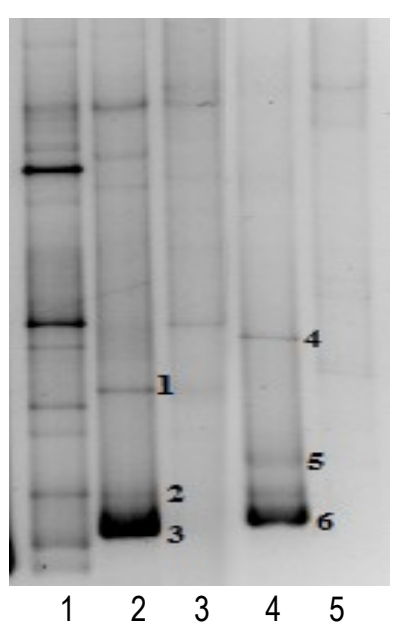

Рис. ДГГЭ продуктов амплификаџии генов $16 \mathrm{~S}$ рРНК с препаратов суммарной ДНК образцов грунта и шлама и накопительных культур (НК). $1-H к 2$ с бифенилом в качестве субстрата; 2 - НК2 с орто-ФК в качестве субстрата; 3 -образеи техногеннозагрязненного грунта вблизи солеотвала; 4 - НК1 с орто-ФК в качестве субстрата; 5 -образец с поверхности шламохранилища

галофильные гаммапротеобактерии рода Halomonas. Данные бактерии преобладали в НК, полученных при культивировании на орто-фталате, следовательно, можно предположить, что галофильные бактерии данного вида участвуют в процессе деструкции орто-фталата в условиях засоления.

Из полученных НК было выделено 55 штаммов бактерий. Установлено, что 21 штамм способен к эффективному росту в жидкой минеральной среде на орто-ФК (1 г/л) в качестве субстрата. Максимальное значение оптической плотности культур $\left(\mathrm{OП}_{600}\right)$ штаммов-деструкто-

Таблица 1

Результаты филогенетического анализа элюированных из геля фрагментов гена16S pPHK

\begin{tabular}{|c|c|c|c|c|}
\hline $\begin{array}{c}\text { Накопи- } \\
\text { тельная } \\
\text { культура }\end{array}$ & $\begin{array}{c}\text { Номер } \\
\text { полосы } \\
\text { (ДГГЭ) }\end{array}$ & $\begin{array}{c}\text { Типовой штамм ближайшего родственного } \\
\text { вида и номер в базе данных GenBank }\end{array}$ & $\begin{array}{c}\text { Сходство } \\
\text { фрагмента } \\
\text { гена } \\
16 \mathrm{~S} \text { рРНК, \% }\end{array}$ & $\begin{array}{c}\text { Кол-во } \\
\text { анализиро- } \\
\text { ванныХ } \\
\text { нуклеотидов }\end{array}$ \\
\hline \multirow{3}{*}{$\begin{array}{c}\text { HK1 } \\
\text { (opmo-ФК) }\end{array}$} & 4 & 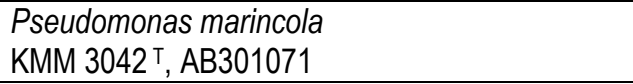 & 96 & 491 \\
\hline & 5 & Gracilimonas tropica CL- CB462 ${ }^{\top}$, NR_044361 & 80 & 491 \\
\hline & 6 & Halomonas ventosae $\mathrm{Al} 12^{\top}$, NR 042812 & 89 & 478 \\
\hline \multirow{3}{*}{$\begin{array}{c}\text { HK2 } \\
\text { (opmo-ФK) }\end{array}$} & 1 & Halomonas salina ATCC 49509', NR_119189 & 67 & 502 \\
\hline & 2 & Halomonas sediminicola CPS11T, NR_152067 & 96 & 487 \\
\hline & 3 & Halomonas ventosae Al12 ${ }^{\top}$ DSM 15911 ${ }^{\top}$ & 99 & 478 \\
\hline
\end{tabular}


ров при выращивании в МСР с орто-ФК в качестве субстрата в присутствии 30 г/л $\mathrm{NaCl}$ варьировалось от 0,45 до 0,86 ед.

Выделенные штаммы-деструкторы opmо-ФК отличались морфологией колоний и клеток, а также способностью к утилизации ароматических углеводородов. Наибольшее количество - 10 штаммов-деструкторов орто-ФК было изолировано из образца, отобранного с поверхности шламохранилища. На основании определения нуклеотидных последовательностей и последующего биоинформационного анализа гена 16S рРНК выделенные штаммы, обозначенные PP22-1 PSH17-51 PP23-2, PP2223, PSH17-1, PSH17-52, PHS18-2, 1B-3, PSH18-3, PР23-1, идентифицированы как представители родов Idiomarina, Rhodococcus, Oceanisphaera, Martelella, Nitratireductor и Marinobacter. Семь деструкторов орто-ФК были изолированы из образца донных отложений сточного канала ООО «Промканал» (штаммы PG1, PD135, PG2, B23, PD13-12, PD13-22 и PD13-42), идентифицированы как представители родов Halomonas, Pseudomonas, Alcanivorax, Bacillus, Arthrobacter u Stappia. Из накопительных культур с использованием образца донных отложений р. Зырянка выделено три деструктора орто-ФК, идентифицированных как представители родов Bacillus, Erythrobacter, Rhodococcus. Три деструктора орто-ФК были выделены из накопительной культуры с использованием образца ризосферы бескильницы расставленной (солеотвал БКПРУ-3). Показано, что выделенные штаммы принадлежали к родам Arthrobacter, Bacillus, Erythrobacter. Из образца донных отложений рассолосборника изолировано два деструктора, идентифицированных как представители родов Rhodococcus и Idiomarina.

В результате скрининга из рабочей коллекции микроорганизмов Лаборатории молекулярной микробиологии и биотехнологии «ИЭГМ УрО РАН» для исследования было отобрано 11 активных деструкторов орто-ФК, представителей разных таксономических групп: родов Bacillus, Rhodococcus, Dietzia, Halomonas,
Alcanivorax, Pseudomonas, Exiguobacterium и Citromicrobium, кроме того - 8 штаммов-деструкторов орто-ФК, относящихся к семейству Micrococcaceae (родов Arhrobacter, Glutamicibacter, Pseudoarthrobacter).

Исследуемые штаммы-деструкторы проверены на способность к росту при повышенном засолении среды культивирования. Установлено, что все выделенные и отобранные из рабочей коллекции лаборатории штаммы росли как в средах без добавления соли, так и при повышенной концентрации $\mathrm{NaCl}$ (до 90 г/л) и были отнесены к галотолерантным микроорганизмам по классификации Кашнера [2]. Штаммы Idiomarina sp. PSH17-1 и Marinobacter sp. РP22-23 не способны к росту в среде без добавления $\mathrm{NaCl}$ и отнесены к галофильным микроорганизмам. При этом 5 штаммов росли при 120 г/л $\mathrm{NaCl}$ в среде, а три штамма BFL6, BFL15 и BO33 в присутствии 150 г/л $\mathrm{NaCl}$. Отобранные из рабочей коллекции штаммы рода Arthrobacter росли в среде с орто-ФК (1 г/л) при содержании 0-60 г/л $\mathrm{NaCl}$ и в полноценной среде при содержании 100 г/л $\mathrm{NaCl}$, и также были отнесены к галотолерантным микроорганизмам.

Все выделенные и отобранные из рабочей коллекции штаммы-деструкторы орто-ФК проверены на способность к утилизации ряда ароматических углеводородов. Установлено, что наиболее широкой субстратной специфичностью из выделенных и отобранных из рабочей коллекции штаммов обладают грамположительные штаммы Bacillus spp. BO4, BO33, а также Rhodococcus sp. PP22-1 и KT723, способные кроме деструкции фталатов (орто-ФК, ДБФ) к росту на нафталине, бифениле, бензоате, нафталине и салицилате. Широким рядом утилизируемых моно- и полиароматических углеводородов обладают также грамотрицательные штаммы Martelella sp. PSH17-4 и Halomonas sp. PG1. Восемь выделенных и семь отобранных штаммов растут на ДБФ - токсичном производном соединении фталевой кислоты. 
Большинство штаммов-деструкторов орто-ФК способны к росту на протокатеховой кислоте (ПКК) - основном метаболите орто-ФК. На основании полученных результатов (рост на орто-ФК, ПКК) можно предположить, что утилизация ДБФ исследуемыми штаммами осуществляется через стадии образования орто-ФК и ПКК до основных продуктов жизнедеятельности микробной клетки, как показано на примере ранее исследованных бактерий $[10,17]$.

У 8 активных деструкторов ДБФ с использованием метода хромато-масс-спектрометрии изучено влияние засоления среды на утилизацию фталатов (ДБФ и ДЭФ). Показано, что большинство штаммов (а именно штаммы Halomonas sp. PG1, Pseudomonas sp. PG2, Oceanisphaera sp. PP23-2, Dietzia sp. 1BR, Rhodococcus sp. PP22-1) в течение 72 ч утилизировали от $90,6 \%$ до 98,6 \% ДБФ в среде без добавления соли и при солености среды 50 г/л $\mathrm{NaCl}$. Повышение содержания $\mathrm{NaCl}$ в среде до 70 г/л существенно не влияло на разложение ДБФ для штаммов PG1, PG2, 1BR и PP22-1. Для штамма Oceanisphaera sp. PР23-2 повышение со- ли снижало степень деструкции ДБФ до 79,6 и 75,7\% (70 и 90 г/л NaCl, соответственно). У штамма Rhodococcus sp. PD10-1 показатели утилизации ДБФ были выше при содержании соли в среде до 50 и 70 г/л (90 и 98,9\%, соответственно), чем при культивировании без соли и при высокой концентрации - 90 г/л $\mathrm{NaCl}(78,2$ и 80\%, соответственно) (табл. 2).

Штаммы-деструкторы рода Martelella демонстрировали более низкие показатели деструкции ДБФ, по отношению с деструкцией ДБФ другими штаммами, как в отсутствие соли в среде культивирования $(63,4 \%$ и 73\%), так и при всех исследуемых повышенных концентрациях соли (см. 2).

Утилизация ДЭФ данными штаммами составляла от $62,0 \%$ до 79,0\% при содержании $\mathrm{NaCl}$ в среде до 70,0 г/л (табл. 2, 3). Существенное снижение степени разложения ДЭФ для исследуемых штаммов наблюдалось при содержании 90 г/л $\mathrm{NaCl}$ (до $46-65 \%$ ) (табл. 3).

В ряде исследований показана способность различных по таксономической принадлежности бактерий к утилизации эфиров фталевой кислоты. Так, полная

Таблица 2

Степень утилизации ДБФ (\%) при разной солености среды

\begin{tabular}{|l|c|c|c|c|}
\hline \multirow{2}{*}{ Штаммы } & \multicolumn{4}{c|}{$\mathrm{NaCl}$ (г/л) } \\
\cline { 2 - 5 } & $\mathbf{5 e 3 ~} \mathbf{~ N a C l}$ & $\mathbf{5 0}$ & $\mathbf{7 0}$ & $\mathbf{9 0}$ \\
\hline Halomonas sp. PG1 & $92,0 \pm 4,8$ & $94,0 \pm 4,4$ & $97,2 \pm 1,2$ & $88,8 \pm 5,2$ \\
\hline Pseudomonas sp. PG2 & $99,6 \pm 1,0$ & $98,6 \pm 1,0$ & $98,0 \pm 1,4$ & $88,0 \pm 6,6$ \\
\hline Oceanisphaera sp. PP23-2 & $90,6 \pm 4,6$ & $92,0 \pm 3,6$ & $79,6 \pm 3,0$ & $75,0 \pm 4,7$ \\
\hline Dietzia sp. 1BR & $91,5 \pm 4,9$ & $92,0 \pm 4,2$ & $92,4 \pm 5,6$ & $86,0 \pm 5,8$ \\
\hline Rhodococcus sp. PP22-1 & $95,6 \pm 2,8$ & $95,8 \pm 3,6$ & $90,8 \pm 7,6$ & $80,2 \pm 6,0$ \\
\hline Martelella sp. PSH17-4 & $63,4 \pm 3,4$ & $65,2 \pm 2,8$ & $56,2 \pm 2,8$ & $48,0 \pm 2,2$ \\
\hline Rhodococcus sp. PD10-1 & $78,2 \pm 1,8$ & $90,0 \pm 4,0$ & $98,9 \pm 1,1$ & $80,0 \pm 3,0$ \\
\hline Martelella sp. PSH17-52 & $73,0 \pm 0,8$ & $76,0 \pm 4,0$ & $62,2 \pm 2,0$ & $50,0 \pm 2,8$ \\
\hline
\end{tabular}

Степень утилизации ДЭФ (\%) при разной солености среды

Таблица 3

\begin{tabular}{|l|c|c|c|c|}
\hline \multirow{2}{*}{ Штаммы } & \multicolumn{4}{c|}{$\mathrm{NaCl}$ (г/л) } \\
\cline { 2 - 5 } & $\mathbf{5 e 3 ~} \mathbf{~ a C l}$ & $\mathbf{5 0}$ & $\mathbf{7 0}$ & $\mathbf{9 0}$ \\
\hline Halomonas sp. PG1 & $64,6 \pm 4,1$ & $75,3 \pm 7,3$ & $69,0 \pm 5,0$ & $59,3 \pm 3,4$ \\
\hline Pseudomonas sp. PG2 & $71,0 \pm 2,0$ & $80,6 \pm 3,4$ & $74,5 \pm 4,0$ & $60,0 \pm 2,0$ \\
\hline Oceanisphaera sp. PP23-2 & $74,3 \pm 5,2$ & $72,1 \pm 4,3$ & $61,3 \pm 3,4$ & $54,3 \pm 6,6$ \\
\hline Dietzia sp. 1BR & $59,0 \pm 4,8$ & $76,0 \pm 2,0$ & $64,2 \pm 1,2$ & $58,0 \pm 2,0$ \\
\hline Rhodococcus sp. PP22-1 & $56,6 \pm 4,2$ & $62,0 \pm 7,0$ & $56,0 \pm 5,8$ & $53,3 \pm 7,3$ \\
\hline Martelella sp. PSH17-4 & $62,6 \pm 4,0$ & $79,0 \pm 7,0$ & $73,2 \pm 3,0$ & $49,0 \pm 6,0$ \\
\hline Rhodococcus sp. PD10-1 & $49,3 \pm 4,1$ & $65,0 \pm 3,0$ & $68,6 \pm 3,4$ & $46,0 \pm 4,3$ \\
\hline Martelella sp. PSH17-52 & $73,7 \pm 2,1$ & $78,3 \pm 4,2$ & $70,8 \pm 2,0$ & $65,0 \pm 2,0$ \\
\hline
\end{tabular}


деструкция ДБФ и ДЭФ (300 мг/л) в течение 30 часов описана для штамма Variovorax sp. BS1. При этом только для штамма Sphingobium sp. ТЈ выявлена способность осуществлять деградацию ДБФ (500 мг/л) при засолении среды до 40 г/л $\mathrm{NaCl}[6,7,13]$. Исследуемые нами штаммы утилизировали ДБФ и ДЭФ в количестве 500 мг/л как в отсутствии соли, так и в присутствии 90 г/л $\mathrm{NaCl}$ в среде культивирования, что позволяет отнести их к эффективным деструкторам ДБФ и ДЭФ, адаптированным к росту и проявлению деградационных свойств в условиях высокого засоления среды.

Таким образом, полученные результаты показывают, что выделенные из техногеннозагрязненных / засоленных образцов (почв, донных отложений водных объектов и шламохранилищ на территории соледобывающего предприятия) бактерии-деструкторы фталатов (орто-ФК, ДБФ, ДЭФ) характеризуются таксономическим разнообразием, обладают широкой субстратной специфичностью, способностью к эффективной утилизации фталатов при повышенном засолении среды. Установлено, что выделенные штаммы-деструкторы орто-ФК являются представителями классов Actinobacteria, Bacilli, Alphaproteobacteria и Gammaproteobacteria. В результате проведенных исследований предложены метаболические пути деструкции фталатов (ДБФ, орто-ФК) для грамположительных и грамотрицательных бактерий деструкторов. Из единичных сообщений известны данные о способности бактерий родов Halomonas и Martelella к росту на орто-ФК [11], но не исследованы физиологические и молекулярно-биологические особенности деструкции этих соединений. Полученные результаты (в том числе выделенные бактерии-деструкторы фталатов) могут служить основой для разработки эффективных биотехнологий детоксикации фталатов в промышленных отходах, а также биоремедиации техногеннозагрязненных почв.

\section{Библиографический список}

1. Баритейн Р.С. Кирилович В.И., Носовский Ю.Е. Пластификаторы для полимеров - М.: Химия, 1982. $200 \mathrm{c.}$

2. Кашнер Д. Жизнь микробов в экстремальных условиях - М.: - Мир, 1981. - 365 с.

3. Практикум по агрохимии: учеб. пособие / под ред. В.Г. Минеева. - М.: МГУ, 2001. - 689 с.

4. Розанова Е.П., Назина Т.Н. Углеводородокисляющие бактерии и их активность в нефтяных пластах // Микробиология. - 1982. - 51. - С. 324-348.

5. Iwaki H., Nishimura A., Hasegawa Y. Isolation and characterization of marine bacteria capable of utilizing phthalate // World J. Microbiol. Biotechnol. - 2012. - Vol. 28. - P. 1321-1325.

6. Jin D., Liang R.X., Dai Q.-Y., Zhang R.Y. Biodegradation of di-n-butyl phthalate by Rhodococcus sp. JDC11 and molecular detection of 3,4-phthalate dioxygenase gene // J. Microbiol. Biotechnol. - 2010. Vol. 20. - № 10. - P. 1440-1445.

7. Jin D., Kong X., Li Y., Bingjian C., Zhihui B., Zhuang H. Biodegradation of di-n-butyl phthalate by a newly isolated halotolerant Sphingobium sp. // Int. J. Mol. Sci. - 2013. - Vol. 14. - P. 24046-24054.

8. Jin D., Kong X., Li Y., Bai Z., Zhuang G., Zhuang X., Deng Y. Biodegradation of di-n-butyl phthalate by Achromobacter sp. isolated from rural domestic wastewater // Int. J. Environ. Res. Public Health. - 2015. Vol. 12. - P. 13510-13522.

9. Lane D.J., Stackebrandt E., Goodfellow M. 16S/23S rRNA sequencing. In: Nucleic acid techniques in bacterial systematics / ed. D.J. Lane, - New York.: John Wiley and Sons, 1991. - P. 115-175.

10. Liang D.W., Zhang T., Fang H. Phthalates biodegradation in the environment // Appl. Microbiol. Biotechnol. - 2008. - Vol. 80. - P. 183-198.

11. Monzon G.C., Nisenbaum M., Seitz M.K.H., Murialdo S.E. // Current Microbiology. - 2018. - Vol. 75. P. $1108-1118$

12. Muyzer G., de Waal E.C., Uitterlinden A.G. Profiling of complex microbial populations by denaturing gradient gel electrophoresis analysis of polymerase chain reaction-amplified genes coding for 16S rRNA // Appl. Environ. Microbiol. - 1993. - Vol. 59. - P. 695-700.

13. Prasad B., Suresh S. Biodegradation of Dimethyl Phthalate, Diethyl Phthalate, Dibutyl Phthalate and Their Mixture by Variovorax Sp. // Int. J. Environ. Sci. Develop. - 2012. - Vol. 3. - № 3. - P. 283-288.

14. Stanislauskienè R., Rudenkov M., Karvelis L., Gasparavičiūtè R., Meškienè R., Časaitè V., Meškys R. Analysis of phthalate degradation operon from Arthrobacter sp. 68B // Biologija. - 2011. - Vol. - 57. - № 3. - P. 45-54. 
15. Stingley R. L., Khan A. A., Cerniglia C. E. Molecular characterization of a phenanthrene degradation pathway in Mycobacterium vanbaalenii PYR-1 // Biochem. Biophys. Res. Commun. - 2004. - Vol. 322. - P. 133-146.

16. Tiirola M.A., Männistö M.K., Puhakka J.A., Kulomaa M.S. Isolation and characterization of Novosphingobium sp. Strain MT1, a dominant polychlorophenol-dagrading strain in a groundwater bioremediation system // Appl. Environ. Microbiol. - 2002. - Vol. 68. - P. 173-180.

17. Vamsee-Krishna C., Mohan Y., Phale P. Biodegradation of phthalate isomers by Pseudomonas aeruginosa PP4, Pseudomonas sp. PPD and Acinetobacter lwoffii ISP4. // Appl. Microbiol. Biotechnol. - 2006. Vol. 72. - P. 1263-1269.

18. Wen Z.D., Gao D.W., Wu W.M. Biodegradation and kinetic analysis of phthalates by an Arthrobacter strain isolated from constructed wetland soil // Appl. Microbiol. Biotechnol. - 2014. - V. 98. - P. 4683-4690.

\title{
NEW BACTERIA-DESTRUCTORS OF PHTHALATES FROM THE AREA OF THE VERKHNEKAMSK SALT DEPOSIT: MOLECULAR BIOLOGICAL CHARACTERISIZATION AND BIOTECHNOLOGICAL POTENTIAL
}

\author{
E.G. Plotnikova, O.V. Yastrebova, A.A. Pyankova, E.S. Korsakova, A.O. Voronina \\ Institute of Ecology and Genetics of Microorganisms UB RAS
}

The study aims to solve the urgent problem of purification of environmental objects from persistent organic pollutants, in particular phthalates as one of the most representative groups. In the course of the research, sampling and chemical analysis of 12 samples of contaminated / saline soils and potash production wastes (Berezniki, Perm Region) was carried out. 55 strains-destructors of ortho-phthalic acid were isolated from the enrichment cultures (EC), derived from these samples. Based on the analysis of 16S rRNA gene fragment, isolated strains have been identified as members of the genera Arthrobacter, Bacillus, Erythrobacter, Rhodococcus, Idiomarina, Martelella, Marinobacter, Oceanisphaera, Halomonas, Alcanivorax, Stappia and Pseudomonas. 20 strains capable of growth on ortho-PA were selected from the working collection of microorganisms (Laboratory of Molecular Microbiology and Biotechnology, Institute of Ecology and Genetics of Microorganisms, UB RAS). It was established that the isolated and selected strains-destructors of ortho-PA are capable to utilize a number of mono- and polyaromatic hydrocarbons, as well as to grow on media with an increased concentration of $\mathrm{NaCl}$ (up to $100 \%$ ). Eight strains of the genera Halomonas, Pseudomonas, Oceanisphaera, Dietzia, Rhodococcus, Martelella were capable of using phthalic acid esters - dibutyl phthalate (DBP) and diethyl phthalate (DEP) as a substrate. Strains utilized $90-98 \%$ DBP and $49-80 \%$ DEP $(500 \mathrm{mg} / \mathrm{l})$ without salt in the culture medium and in the presence of $50 \mathrm{~g} / \mathrm{l} \mathrm{NaCl}$. As a result of research, active strains-destructors of phthalates were identified adapted to growth under conditions of increased salinization of the environment, promising for the development of methods for bioremediation of technologically contaminated soils.

Keywords: aerobic bacteria, ortho-phthalic acid, dibutyl phthalate, diethyl phthalate, destruction, sodium chloride.

\section{Сведения об авторах}

Плотникова Елена Генриховна, доктор биологических наук, ведущий научный сотрудник лаборатории молекулярной микробиологии и биотехнологии, Институт экологии и генетики микроорганизмов УрО РАН РАН - филиал Пермского федерального исследовательского центра УрО РАН (ИЭГМ УрО РАН), 614081, г. Пермь, ул. Голева, 13; e-mail: peg@iegm.ru

Ястребова Ольга Викторовна, кандидат биологических наук, научный сотрудник лаборатории молекулярной микробиологии и биотехнологии, ИЭГМ УрО РАН; e-mail: olyastr@mail.ru

Корсакова Екатерина Сергеевна, кандидат биологических наук, научный сотрудник лаборатории молекулярной микробиологии и биотехнологии, ИЭГМ УрО РАН; e-mail: korsakovaekaterina08@gmail.com

Пьянкова Анна Александровна, инженер 1-й категории лаборатории молекулярной микробиологии и биотехнологии, ИЭГМ УрО РАН; e-mail: annpjankva@mail.ru

Воронина Анна Олеговна, инженер лаборатории молекулярной микробиологии и биотехнологии, ИЭГМ УрО РАН; e-mail: voroninaao@gmail.com 